\title{
SCHOOL WELLBEING ON SENIOR HIGH SCHOOL STUDENTS IN COVID-19 PANDEMIC ERA
}

\author{
Mustami'ah Dewi, Arya Lutfi, Putri Ajeng Cahyani \\ Universitas Hang Tuah, Surabaya, Indonesia \\ *E-mail: dewi.mustamiah@hangtuah.ac.id
}

\begin{abstract}
School wellbeing is an important thing for students to have, because they can study calmly and comfortable so that learning achievement will be achieved. This research was conducted at a Vocational High School in the coastal area of Surabaya. The results show that the wellbeing of students is dominant in the sufficient category $(70.491 \%)$. Students feel comfortable with school conditions, social relations in the school environment are quite smooth, students have the opportunity to manifest themselves and students feel happy when at school. Meanwhile, $16.393 \%$ feel uncomfortable, social relations at school are not smooth, unhappy, and feel that school does not provide opportunities to fulfil themselves. And only $13.11 \%$ of students are comfortable with school conditions, social relations are smooth, happy and school gives opportunities to fulfil themselves.
\end{abstract}

\section{KEY WORDS}

School wellbeing, having, loving, being, health.

School as an institution designed for students to get the education. Schools are expected to be able to carry out their functions optimally to help students gain knowledge and hone skills that will be used in later life in society (Holander in Bachrie, 2009). Every school should be dedicated to create students who are able to carry out their duties well in school, confident and ready to face the problems that arise in life, and schools must focus on developing well-being, by making students happy, healthy, more productive and able to develop according to their function as students (Eckersley, 2013).

Well-being is a concept which is formed from various experiences and individual functions as a whole human being (Ryff et.al., 1996). The application of well-being in schools is termed as school well-being (Konu and Rimpela, 2002). Allardt (in Konu and Rimpela 2002) himself defines that well-being as a condition that allows individuals to feel satisfied that their basic needs at school include having, loving, and being.

This concept was aimed that school well-being students is more important, especially the students' feelings in assessing the feasibility of the school as a learning environment that is able to provide support, security, and comfort.

School well-being is applied in schools because the level of student satisfaction at school plays a role in students' feelings at school, both positive and negative feelings. The interaction between the three will determine how the condition of school well-being is felt by students at school.

The above opinion is reinforced by research which conducted by Zahra and Airnti (2013) through their research which also states that school well-being plays an important role in schools because it can increase the academic achievement of accelerated program students. This feeling of well-being is felt by students because students feel that all their developmental needs are fulfilled while being civilized at school. In addition, this study also states that the availability of good school facilities, good teacher quality, and adequate health services are the reasons why students generally judge that their school wellbeing has been fulfilled.

Students who have low or less pleasant of school wellbeing may be a significant source of stress and reduce the quality of life for students (McCullough, 2000). McCullough's statement is supported by Fatimah's research (2010), which shows that a comfortable school 
can make students achievement, whereas if students feel unhappy and comfortable at school, it can make students feel unhappy and decrease their academic grades at school.

Research related to school wellbeing that conducted by Utami et al (2011) which was conducted on 301 students showed that 89 of 301 students $(30 \%)$ had negative school wellbeing. The biggest problem is that there is no good relationship between teachers and students; the teacher's lack of attention to students makes communication between teachers and students were difficult.

\section{LITERATURE REVIEW}

School wellbeing refers to the conceptual model of wellbeing from Allardt, which was the fulfilment of certain needs in humans (Konu et al, 2002). Wellbeing is a multidimensional construct that has an impact on both positive and negative attitudes. Diener, 1984; Tian, 2008). On the basis of this opinion, the concept of school wellbeing was developed, such as the concept of a safe, comfortable and pleasant school and the fulfilment of the basic needs of students at school (Konu et al, 2002). School wellbeing can also be interpreted as a student's assessment of the overall condition of the school that has a positive or negative effect on student life at school (Tian et al., 2013).

School well-being for students is a positive emotional life resulting from harmony between environmental factors, personal needs, and student expectations at school (Engels et al., in O'Brien, 2008). The main goal is not only to fulfil the wellbeing of students, but also to fulfil the achievements, potentials, and physical and mental abilities of students (Konu \& Rimpelä, 2002).

There are four aspects in the concept of school wellbeing, such as:

a) Having (school conditions); Related to the condition of the school, both the physical environment and the school situation. Physical conditions include a safe, comfortable environment, adequate air ventilation, protected from noise, appropriate temperature and so on while the classroom situation is related to learning, curriculum, lesson schedules, and existing rules. Also related to school services, for example the existence of counselling services, homeroom teachers, lunch and so on;

b). Loving (Social relations). Students feel comfortable because there are good social relationships at school. The relationship between teachers and students is well established, students can interact with their friends at school, and the relationship between students and all communities in the school runs smoothly. The relationship between school and home is well established, the school atmosphere is felt to provide a sense of comfort, so students feel part of members in the school;

c). Being (self-fulfilment). Students who are in school are accepted, so students are considered to have the same rights as others. Students are involved in making decisions at school, so students feel their existence is recognized. This condition makes students feel valued by teachers, friends and members of the school community (Konu et al., 2002);

d). Health Status. This student's health status includes physical and mental aspects in the form of psychosomatic symptoms, chronic diseases, minor illnesses (such as flu), and appreciation of self (Konu et al., 2002).

Factors that influence school wellbeing which adapted to the school context are social relationships, friends and free time, volunteering, social roles, personality characteristics that include self-esteem, internal locus of control, self-efficacy, inspirational goals, learning orientation seeking meaning, and the ability to empathize (Keyes et al., 2008). Gender affects school wellbeing (Keyes et al., 2008).

\section{METHODS OF RESEARCH}

The study uses a descriptive method with a quantitative approach, which is an analysis of data by describing or describing the data that has been collected as it is without intending to make conclusions that apply to the public (Sugiyono, 2015). So in the implementation of this research, it is carried out using quantitative descriptive methods, which is a form of 
research based on data collected during research systematically about the facts and properties of the object under study, then interpreted based on theories and literature related to school wellbeing.

This method aims to provide a fairly clear picture of the school wellbeing of the students being studied. In this study, the authors obtained data using the school wellbeing scale which then the data will be calculated statistically.

The population in this study was students at SMK $X$ in the coastal area of East Surabaya. Because the number of students who can be contacted and have gadgets is only 61 students, the research subjects are 61 students which consisting of 26 female students and 35 male students. The sampling technique used is saturated sampling (Arikunto, 2019).

The data collection technique used in this research is the school wellbeing scale which is constructed from the opinion of Konu et. al (2002).

Table 1 - The Blueprint of School Wellbeing

\begin{tabular}{lll}
\hline Indicators & Sub-Indicators & Amount \\
\hline Having & 1. Air ventilation in the school is clean & 10 \\
& 2. Subjects and schedules received by students are clear & \\
& 3. Counselling health services in schools & 10 \\
\hline Loving & 1. Students feel the relationship with the teacher is good & \\
& 2. Can Discuss with teachers and classmates \\
& 3. Feel comfortable with classmates & 10 \\
\hline Being & 1. Opportunity for students to be part of the school community \\
& 2. Students assist in the structure of the student council president election & \\
\hline Health Status & 3. Development of students' talents and interests can be fulfilled at school & 10 \\
\hline TOTAL & 2. Students give a clean and comfortable environment & 40 \\
\hline
\end{tabular}

Based on these aspects, it is arranged into a school wellbeing scale consisting of 40 items. The scale that has been arranged is then creamed to the respondent by a Google form. This is based on the consideration of students when the research is taking place while learning from home (online). Because 61 students have gadgets, all of them are used as research subjects.

The data analysis technique in this study uses descriptive analysis techniques, which is the thought process to take general understandings or conclusions based on specific concrete data or facts. Non-experimental quantitative research data analysis can be carried out using statistical formulas, it can also be simple statistics in the form of means, standard deviations, cross tabulations, and presented in the form of tables, charts or graphs (Arikunto, 2019).

\section{RESULTS AND DISCUSSION}

The design that chosen is a descriptive research and which provides the researcher with sufficient data about the population and provides answers about the "who, what, where and when" of the research problem. It also provides appropriate information by describing the existing conditions and is considered appropriate for this study to reveal answers about school wellbeing.

In this study, to measure school wellbeing by making a measurement scale of School Wellbeing which was constructed from the theory of Konu et al. (2002) which consists of 4 aspects, such as: Having, Loving, Being and Health Status. Based on these aspects, it was developed into 40 items, which divided into; having 10 items, loving 10 items, being 10 items and health status 10 items. All items can be used. This is based on the opinion that after the school wellbeing scale is filled in by students then it is tabulated and analysed for validity and reliability. The results show that the discrimination index of 26 items exceeds 0.3 , from 0.325 - 0766, so it has a Health Status index (Azwar, 2013). And then analysed the reliability with Cronbach's alpha the results showed 0.915 . Thus it is included in the very high category (Arikunto, 2013). 
Table 2 - Results of School Wellbeing Frequency Analysis between Boys and Girls

\begin{tabular}{llllllll}
\hline Gender & $\mathrm{N}$ & Mean & Standard Deviation & Median & Mode & Minimum & Maximum \\
\hline Male & 35 & 112.1143 & 16.93720 & 113 & 98 & 80 & 156 \\
\hline Female & 26 & 130.3846 & 10.60218 & 128.5 & 133 & 115 & 157 \\
\hline
\end{tabular}

Based on table 2, it is known that the average school wellbeing of female students is higher than the average of male students. The average school wellbeing for female is 130.3846 while school wellbeing for male is 112.1143 . The minimum score obtained by male students is lower than the minimum score obtained by female students, namely 80 for male students and 115 for female students. Likewise, the maximum score obtained by female students is higher than the maximum score obtained by male students, which was 156 for a male maximum score, 157 for a female maximum score. The standard deviation of men is greater than the score of the standard deviation of women, namely, men are 16.93720 and women are 10.60218. Thus it can be concluded that the school wellbeing of female students is higher than male students.

School wellbeing of students in a Vocational Shool in the Kenjeran area shows the following results:

Table 3 - School wellbeing Description

\begin{tabular}{llll}
\hline Category & Average & Frequency & Percentage (\%) \\
\hline Tinggi & $137 \leq X$ & 8 & $13.12 \%$ \\
\hline Sedang & $103 \leq X \leq 137$ & 43 & $70.49 \%$ \\
\hline Rendah & $X<103$ & 10 & $16.39 \%$ \\
\hline Total & & 61 & $100 \%$ \\
\hline
\end{tabular}

From the results of table 3 , it is known that the school wellbeing research subject is dominant in the medium category, which are $75 \%$, in the high category $11 \%$ and in the low category by $13 \%$. This shows that vocational students in the East coast of Surabaya perceive that at school students feel comfortable dealing with friends, teachers and school residents. Students also feel involved in school activities, can express their abilities.

And after analysing each aspect, such as having, loving, being and health, the results are known as follows:

Table 4 - Each Aspects Description of School Wellbeing

\begin{tabular}{llllll}
\hline Aspect & Mean & Standard Deviation & Mode & Minimum & Maximum \\
\hline Having & 28.9016 & 4.64652 & 32.00 & 19 & 40 \\
\hline Loving & 30.4754 & 5.01865 & 34.00 & 19 & 40 \\
& & & & & 42 \\
\hline Being & 30.3607 & 5.67754 & 31.00 & 17 & 41 \\
\hline Healthing & 30.1639 & 4.94699 & 29.00 & 21 & \\
\hline
\end{tabular}

Based on table 4, it is known that the highest aspect is being with an average of 30,3607 . This shows that students are given the opportunity to be part of the school community, students are involved in making decisions at school, and students can develop their talents at school. While the second aspect is loving with an average of 30.4754 , meaning that students feel comfortable with the teacher, can discuss, feel comfortable with their friends. The third aspect is health with an average of 30.1639 . This means that students feel mentally happy when they are at school, and students are not easily tired at school. The lowest aspect is having with an average of 28.9016, namely students feel comfortable if the school environment has clean air ventilation, the subjects and schedules received by students are clear, as well as health counselling services in schools.

The results of this study are in accordance to the research of Konu et al (2002) that school wellbeing as a school condition that allows individuals to satisfy their basic needs, which includes having, loving, being and helping. School wellbeing in students is a positive emotional life resulting from harmony between environmental factors, personal needs and student expectations at school (Engels et al, in O'Brien, 2008). The main goal is not only to 
fulfil student wellbeing, but also to fulfil achievement, develop potential both physically and mentally (Konu et al., 2002). also known that:

Based on crosstab analysis between gender and each aspect of school wellbeing, it is

Table 5 - Crosstab between Gender and each Aspects of School wellbeing

\begin{tabular}{lllllllll}
\hline & Having & & Loving & & Being & & Healthy \\
& Male & Female & Male & Female & Male & Female & Male & Female \\
& Students & Students & Students & Students & Students & Students & Students & Students \\
\hline Mean & 27.86 & 33.69 & 28.43 & 33.23 & 27.43 & 30.88 & 28.37 & 32.58 \\
\hline Median & 28 & 33 & 28 & 34 & 26 & 30.5 & 29 & 33 \\
\hline Mode & 25 & 30 & 26 & 34 & 25 & 29 & 29 & 29 \\
\hline $\begin{array}{l}\text { Standard } \\
\text { Deviation }\end{array}$ & 5.64 & 3.74 & 5.23 & 3.09 & 4.86 & 3.55 & 5.08 & 3.61 \\
\hline Range & 23 & 14 & 21 & 13 & 17 & 15 & 20 & 14 \\
\hline Minimum & 17 & 28 & 19 & 27 & 19 & 25 & 21 & 26 \\
\hline Maximum & 40 & 42 & 40 & 40 & 36 & 40 & 41 & 40 \\
\hline
\end{tabular}

Based on table 4, it is known that female students have the highest level of having, which has an average of 33.69 and the lowest aspect was being, which has an average of 30.88. While for male students, the highest score in the aspect of loving, which score 28.43 and the lowest score on the aspect of being which score 27.43. This means that female students feel comfortable if the school environment has clean air ventilation, the subjects and schedules received by students are clear, as well as health counselling services at school. While male students feel comfortable with the teacher, having a discussion, feel comfortable with their friends than female student. However, male and female students at both schools have not provided the opportunity to be part of the school community, students have not been involved in making decisions at school, and female students feel that they have not been able to develop their talents at school.

\section{CONCLUSION}

Based on the results of the study, it is known that the school wellbeing of students at SMK $X$ on the east coast of Surabaya is in the sufficient category. This shows that students are quite comfortable with school conditions, students consider the air ventilation in the school to be sufficient, avoid noise and the room temperature is adequate. In fact, if you look at the school standing in a crowded environment, it doesn't have a yard. However, for school students it is still more comfortable than where students live in dense environments, near the beach and usually without adequate ventilation. Students are also quite able to relate to the social environment, meaning that students are able to establish relationships with friends, teachers and residents in the school environment. This shows that students have the ability to adapt to their environment (Hurlock, 2010). Students also feel valued by teachers, friends and members of the school community (Konu et al., 2002). The results also show that there is a difference between male and female students in school wellbeing. Female students have higher school wellbeing than male students.

From the results of the study it was also found that the aspect of being; students felt less involved in making rules at school. Students feel their existence is still not fully recognized. Conditions can affect students' self-esteem. Therefore, schools need to pay attention to this so that students feel valued. If students feel that their existence is important, it will increase their self-esteem (Konu et al. 2002).

\section{REFERENCES}

1. Azwar, S. (2011). Metode penelitian. Yogyakarta: Pustaka Pelajar.

2. Azwar, S. (2012). Penyusunan Skala Psikologi.Yogyakarta: Pustaka Pelajar. 
3. Hurlock, E. B. (2010). Perkembangan anak jilid 1. Jakarta: Penerbit Erlangga. Edisi keenam.

4. Konu, A.I., \& Rimpela, T. P. (2002). Well-being in school: Aconceptual model. Health Promotion International, 17(1), 79-87.

5. Konu, A., Alanen, E., Lintonen, T., \& Rimpelä, M. (2002). Factor structure of the school well-being model. Health education research, 17(6), 732-742. https://academic.oup.com/her/article/17/6/732/697260 diakses 8 juli 2019.

6. Liu, W., Tian, L., Huebner, E. S., Zheng, X., \& Li, Z. (2015). Preliminary development of the elementary school students' subjective well-being in school scale.Social Indicators Research, 120(3), 917-937.

7. Keyes, C. L. M., \& Waterman, M. B. (2008). Dimension of well-being and mental health in adulthood. In Bornstein, M. H. et al. (Eds), Well-being (Positive development across the life course), 487-491. United Kingdom: Taylor \& Francis e-Library.

8. Konu, A., \& Rimpelä, M. (2002). Well-beig in schools: A conceptual model. Health Promotion International, 17(1). Oxford: Oxford University Press.

9. Konu, A.I. and Lintonen, T.P. (2006). School well-being in Grades 4-12. Health education research, 21(5), pp.633-642. https://academic.oup.com/her/article/21/5/633/750945 diakses 15 juli 2019.

10. O'Brien, M. (2008). Well-being and post-primary schooling. Dublin: NCCA. http://sdpi.ie/NCCA_Materials/NCCA\%20Well-being_report_en.pdf diakses 29 Agustus 2019.

11. O'Brien, M. (2008). Well-being and post-primary schooling: a review of the literature and research. Merrion Square: Dublin.

12. Sugiyono. 2014. Metode Penelitian Pendidikan Pendekatan Kuantitatif, Kualitatif, dan R\&D. Bandung: Alfabeta.

13. Supratiknya, A. (2014). Pengukuran Psikologis. Yogyakarta: Universitas Sanata Dharma

14. Tian, L., Liu, B., Huang, S., \& Huebner, E,S. (2013). Perceived social support and school well-being among chinese early and middle adolescents: The mediational role of selfesteem. Social Indicators Research, 113, 991-1008. 